ARTICLE

\title{
Direct access to spirocycles by Pd/WingPhos- catalyzed enantioselective cycloaddition of 1,3-enynes
}

Long $\mathrm{Li}^{1,4}$, Shan Wang ${ }^{1,4}$, Pengfei Luo ${ }^{1}$, Ran Wang ${ }^{1}$, Zheng Wang (id ${ }^{2}$, Xiaoguang Li (i] ${ }^{3}$, Yuhua Deng ${ }^{1}$, Fangzhi Peng ${ }^{1} \&$ Zhihui Shao (1) ${ }^{1 \times}$

Spirocycles play an important role in drug discovery and development. The direct, catalytic, and enantioselective synthesis of spirocycles from readily available starting materials and in an atom economic manner remains a highly sought-after task in organic synthesis. Herein, an enantioselective Pd-hydride-catalyzed cycloaddition method for the synthesis of spirocyclic compounds directly from two classes of commonly available starting materials, 1,3-enynes and cyclic carbon-hydrogen $(\mathrm{C}-\mathrm{H})$ bonds, is reported. The reactions employ a chiral $\mathrm{Pd} /$ WingPhos catalyst to both suppress the formation of bis-allenyl by-products and control the stereoselectivity. 1,3-Enynes are used as dielectrophilic four-carbon units in the cycloaddition reactions, which also enables an enyne substrate-directed enantioselectivity switch with good levels of stereocontrol. The present spirocycle synthesis tolerates a broad range of functional groups of 1,3-enyne substrates, including alcohols, esters, nitriles, halides, and olefins. A variety of diverse cyclic nucleophiles, including pharmaceutically important heterocycles and carbocycles, can be flexibly incorporated with spiro scaffolds.

\footnotetext{
${ }^{1}$ Key Laboratory of Medicinal Chemistry for Natural Resource, Ministry of Education, School of Chemical Science and Technology, Yunnan Provincial Center for Research \& Development of Natural Products, and State Key Laboratory for Conservation and Utilization of Bio-Resources in Yunnan, Yunnan University, Kunming 650091, China. ${ }^{2}$ Kunming Institute of Physics, Kunming 650223, China. ${ }^{3}$ Institute for Advanced Study, Shenzhen University, Shenzhen 518060 , China. ${ }^{4}$ These authors contributed equally: Long Li, Shan Wang. ${ }^{凶}$ email: zhihui_shao@hotmail.com
} 
pirocyclic scaffolds are widely present in numerous natural products and biologically active compounds ${ }^{1-7}$. Moreover, the uniquely rigid structures of spirocyclic scaffolds can reduce the conformational entropy penalty upon binding to a protein target ${ }^{8,9}$. As a result, spiro scaffolds have been increasingly utilized in drug discovery and development programs ${ }^{8,9}$. The development of efficient asymmetric approaches for constructing spirocyclic compounds has attracted much attention ${ }^{10-18}$. Despite considerable progress in the asymmetric synthesis of spirocycles, the methods that are direct, catalytic, enantioselective, and atom economic ${ }^{19}$ and that rely on the use of commonly available starting materials are in high need.

The direct addition of enols/enolates to unactivated unsaturated hydrocarbons (hydroalkylation) with catalysis by transition-metal hydrides $(\mathrm{MH})$ has been attracting increasing attention as an atomeconomical strategy for the $\mathrm{C}-\mathrm{C}$ bond formation. Elegant progress on asymmetric variants of these reactions has recently been made ${ }^{20-39}$.
However, the potential of this technique in the direct asymmetric synthesis of spirocyclic compounds has remained elusive. Moreover, the reported studies focused on asymmetric mono-hydroalkylation. In contrast, transition-metal-hydride-catalyzed asymmetric annulative double hydroalkylation sequences of unactivated unsaturated hydrocarbons with enols/enolates are scarce. In addition, effective chiral catalyst systems that are applicable to the establishment of asymmetric addition of enols/enolates to unsaturated hydrocarbons are comparatively limited. As our continuous interest in asymmetric cycloadditions ${ }^{40-46}$, we explored the possibility of transition-metal hydride-based cycloaddition strategy for the direct catalytic asymmetric spirocycle synthesis.

Here, we report the successful development of Pd-hydride catalyzed cycloaddition of 1,3-enynes employing P-chiral WingPhos as the ligand that enables the direct, atom-economical, and enantioselective synthesis of spirocycles from two classes of commonly available starting materials (Fig. 1a). The challenging product

a<smiles>[R]C#CC=C</smiles>

1<smiles>[R]/C=C\C#C</smiles>

1<smiles>[X]C1CCCCC1</smiles>

2<smiles>[X]C1CCCCC1</smiles>

2

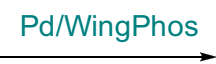

Pd/WingPhos
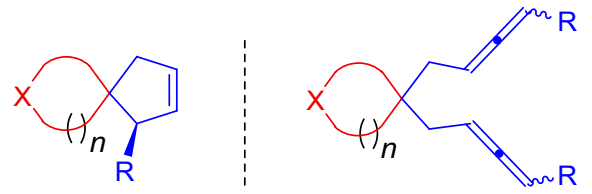

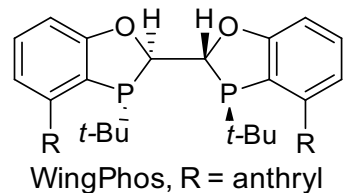
( $P$-chiral ligand)

\footnotetext{
atom economy

- two classes of commonly available starting materials

diverse valuable spirocycles

- PdH-based strategy

product-selectivity

- enantioselectivityswitch by exchanging the position of double bond and triple bond of 1,3-enynes

a Pd/WingPhos catalyst for two mechanistically and stereochemically distinct processes with high enantiocontrol
}

b

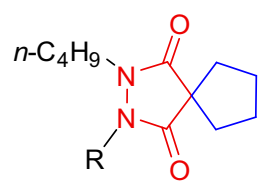

AT1 angiotensinII receptorantagonists<smiles>[R7]C1=NNC(=O)C12CCCC2</smiles><smiles>[R]=[Y]([CH])c1ccc(-n2ccnc2)cc1</smiles>

type 4 phosphodiesterase inhibitors<smiles>O=C1NC(=O)C2(C[C@H](O)[C@@H](CO)C2)C(=O)N1</smiles>

anticancer reagent<smiles>[R]N1C(=O)CC2(CCCC2)CC1=O</smiles>

Buspirone (anxiolytic)
$\mathrm{R}=$<smiles>CCCc1ccc(-c2ccccc2-c2nnn[nH]2)cc1</smiles><smiles>[R]=C=CCCCN1CCN(c2ncccn2)CC1</smiles><smiles>CC1=CC(=O)C2(C1=O)[C@H](C(C)CO)CC[C@H]2C</smiles><smiles>CCCC(=O)C1=C(O)[C@]2(C)COC2C2(CCC2(C)C)C1=O</smiles>

RhodocoraneK (antimycotic)
LalibinoneE (antioxidative)

Fig. 1 Transition-metal hydride-based cycloaddition strategy for the direct catalytic asymmetric spirocycle synthesis. a Pd/WingPhos-catalyzed enantioselective cycloaddition reactions of 1,3-enynes as dielectrophilic C4 synthons. b Selected bioactive spirocyclic molecules relevant to this study. 


\section{Table 1 Chiral ligand effects on product-selectivity and enantioselectivitya.}

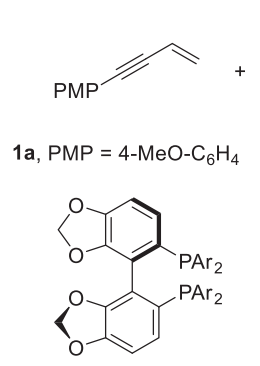

L1, DTBM-SEGPHOS $\mathrm{Ar}=4-\mathrm{OMe}-3,5-(t-\mathrm{Bu})_{2}-\mathrm{C}_{6} \mathrm{H}_{2}$ L2, SEGPHOS, $\mathrm{Ar}=\mathrm{Ph}$<smiles>O=C1CC(=O)N(c2ccccc2)N1c1ccccc1</smiles>

2a

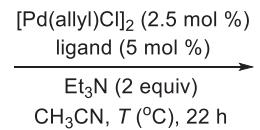

$\mathrm{CH}_{3} \mathrm{CN}, T\left({ }^{\circ} \mathrm{C}\right), 22 \mathrm{~h}$

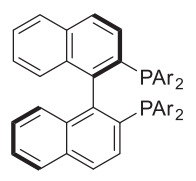

L3, BINAP, $\mathrm{Ar}=\mathrm{Ph}$

L4, $\mathrm{Ar}=3,5-(\mathrm{Me})_{2}-\mathrm{C}_{6} \mathrm{H}_{3}$

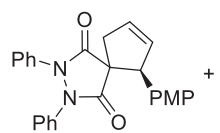

3 aa

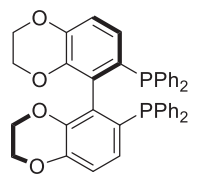

L5, SYNPHOS

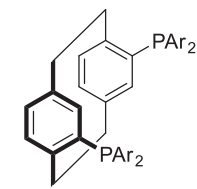

L6, Xylyl-PhanePhos $\mathrm{Ar}=3,5-(\mathrm{Me})_{2}-\mathrm{C}_{6} \mathrm{H}_{3}$
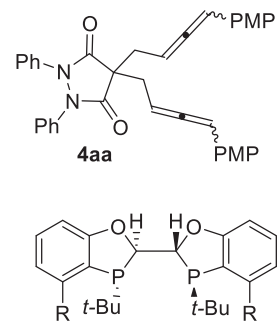

L7, WingPhos, $R=$ anthryl

L8, $\mathrm{R}=\mathrm{Ph}$

L9, $\mathrm{R}=2,5-(\mathrm{OMe})_{2}-\mathrm{C}_{6} \mathrm{H}_{3}$ L10, $\mathrm{R}=\mathrm{H}$

\begin{tabular}{|c|c|c|c|c|c|}
\hline Entry & Ligand & $T\left({ }^{\circ} \mathrm{C}\right)$ & $\begin{array}{l}\text { Yield (\%) } \\
b \text { of } 3 a a\end{array}$ & $\begin{array}{l}\text { Yield (\%) } \\
\mathrm{b} \text { of } 4 \mathrm{aa}\end{array}$ & $\begin{array}{l}\text { ee (\%) } \\
\text { c of 3aa }\end{array}$ \\
\hline 1 & L1 & 50 & 0 & 0 & - \\
\hline 2 & L2 & 50 & 0 & 30 & - \\
\hline 4 & L4 & 50 & 0 & 31 & - \\
\hline 5 & L5 & 50 & 10 & 16 & - \\
\hline 6 & L6 & 50 & 44 & 16 & 21 \\
\hline 9 & L8 & 30 & Trace & 0 & - \\
\hline 10 & L9 & 30 & 16 & 0 & 69 \\
\hline 11 & L10 & 30 & 45 & 0 & 44 \\
\hline
\end{tabular}

aReaction conditions: 1a $(0.12 \mathrm{mmol}), \mathbf{2 a}(0.1 \mathrm{mmol}),\left[\mathrm{Pd}(\right.$ allyl $) \mathrm{Cl}_{2}(2.5 \mathrm{~mol} \%)$, chiral ligand $\left(5 \mathrm{~mol}_{2}\right), \mathrm{Et}_{3} \mathrm{~N}\left(2\right.$ equiv), $\mathrm{CH} \mathrm{C}_{3} \mathrm{CN}(0.5 \mathrm{~mL}), 22 \mathrm{~h}$.

Table 2 Base effects ${ }^{a}$.

\begin{tabular}{|c|c|c|c|c|}
\hline & $1 a$ & $\begin{array}{c}{\left[\begin{array}{c}\mathrm{Pd}(\text { allyl }) \mathrm{Cl}]_{2}(2.5 \mathrm{~mol} \%) \\
\mathbf{L 7}(5 \mathrm{~mol} \%)\end{array}\right.} \\
\underset{\text { base }(2 \text { equiv })}{\mathrm{CH}} \\
\mathrm{CH}_{3} \mathrm{CN}, 30^{\circ} \mathrm{C}, 22 \mathrm{~h}\end{array}$ & $\mathrm{Ph}_{4 \mathrm{a}}^{\mathrm{Nh}}$ & \\
\hline Entry & Base & $\begin{array}{l}\text { Yield (\%) } \\
\mathrm{b} \text { of } 3 \mathrm{aa}\end{array}$ & $\begin{array}{l}\text { Yield (\%) } \\
\mathrm{b} \text { of } 4 \mathrm{aa}\end{array}$ & $\begin{array}{l}\text { ee (\%) } \\
\text { c of 3aa }\end{array}$ \\
\hline 1 & $\mathrm{~K}_{2} \mathrm{CO}_{3}$ & Trace & 0 & - \\
\hline 4 & $\mathrm{Et}_{3} \mathrm{~N}$ & 22 & 0 & 96 \\
\hline 5 & $\mathrm{BnN}(\mathrm{Me})_{2}$ & 71 & 0 & 90 \\
\hline
\end{tabular}

aReaction conditions: $\mathbf{1 a}(0.12 \mathrm{mmol}), \mathbf{2 a}(0.1 \mathrm{mmol}),[\mathrm{Pd}(\text { allyl }) \mathrm{Cl}]_{2}(2.5 \mathrm{~mol} \%), \mathbf{L 7}(5 \mathrm{~mol} \%)$, base (2 equiv), $\mathrm{CH}_{3} \mathrm{CN}(0.5 \mathrm{~mL}), 30^{\circ} \mathrm{C}, 22 \mathrm{~h}$.

blsolated yields.

CDetermined by chiral HPLC.

DIPEA N,N-diisopropylethylamine, PMP 4-methoxyphenyl.

selectivity issue of cycloaddition products versus double intermolecular hydroalkylation products has been addressed. A chiral $\mathrm{Pd} /$ WingPhos catalyst is able to affect both 1,3-enynes $\mathbf{1}$ having a terminal double bond and 1,3-enynes $\mathbf{1}^{\prime}$ having a terminal triple bond to engage in the asymmetric cycloaddition reactions with high levels of enantioselectivity switch. Mechanistic studies suggest that two cycloaddition reactions involve mechanistically and stereochemically distinct processes. For the cycloaddition reaction with 1,3-enynes $\mathbf{1}$, the previously unreported enantioselective intermolecular hydroalkylation step of 1,3-enynes 1 with cyclic enols/enolates forms allene intermediates with axial chirality which serves as a chiral relay during cyclization processes involving a very high efficiency of axial-to central chirality transfer, whereas for the cycloaddition with 1,3-enynes $\mathbf{1}^{\prime}$, the marked stereocenter of the spirocyclic products is directly introduced in the enantioselective intermolecular hydroalkylation step of 1,3-enynes $\mathbf{1}^{\prime}$ with enols/ enolates to form allene intermediates with central chirality, which has not been previously realized. 


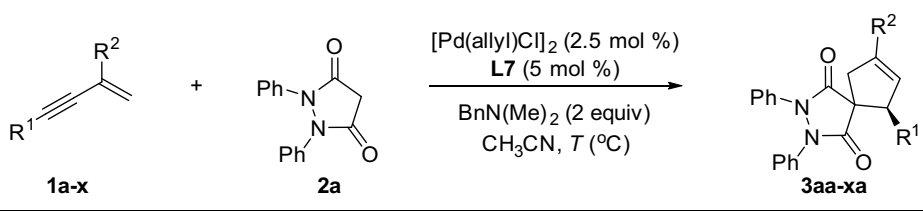

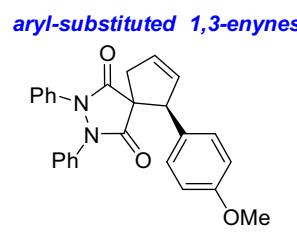

3aa, $30^{\circ} \mathrm{C}, 22 \mathrm{~h}$ $71 \%, 90 \%$ ee

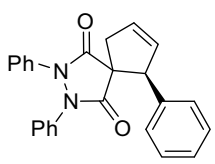

3fa, $30{ }^{\circ} \mathrm{C}, 22 \mathrm{~h}$ $69 \%, 96 \%$ ee

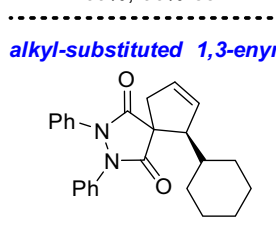

3la, $40^{\circ} \mathrm{C}, 36 \mathrm{~h}$ $58 \%, 96 \%$ ee

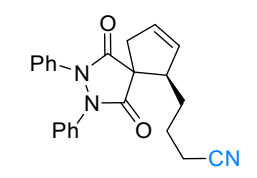

3qa, $40{ }^{\circ} \mathrm{C}, 36 \mathrm{~h}$

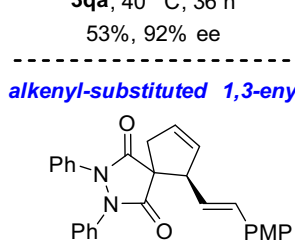

3va, $10{ }^{\circ} \mathrm{C}, 48 \mathrm{~h}$

$50 \%, 80 \%$ ee

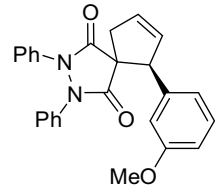

3ba, $30{ }^{\circ} \mathrm{C}, 22 \mathrm{~h}$ $63 \%, 94 \%$ ee

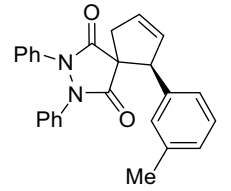

$3 \mathrm{ca}, 30^{\circ} \mathrm{C}, 22 \mathrm{~h}$ $89 \%, 95 \%$ ee

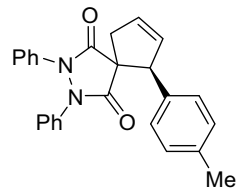

3da, $30^{\circ} \mathrm{C}, 22 \mathrm{~h}$ $84 \%$, $95 \%$ ee

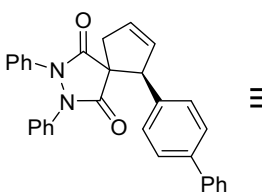

3ea, $30^{\circ} \mathrm{C}, 22 \mathrm{~h}$

$70 \%, 96 \%$ ee

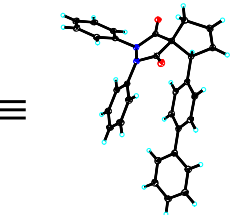

X-ray of 3ea
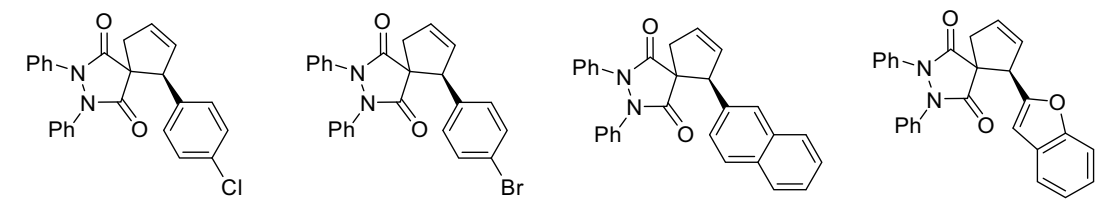

3ja, $30{ }^{\circ} \mathrm{C}, 36 \mathrm{~h}$

$54 \%, 94 \%$ ee

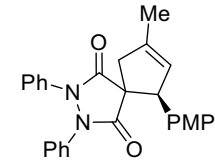

3ka, $30^{\circ} \mathrm{C}, 22 \mathrm{~h}$

3ha, $30^{\circ} \mathrm{C}, 22 \mathrm{~h} \quad 3 i \mathrm{a}, 30^{\circ} \mathrm{C}, 22 \mathrm{~h}$ $60 \%, 96 \%$ ee

$65 \%, 93 \%$ ee

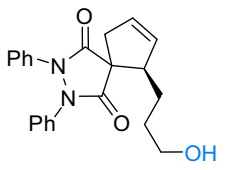

3na, $30^{\circ} \mathrm{C}, 36 \mathrm{~h}$ $60 \%, 95 \%$ ee

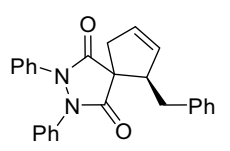

3sa, $40^{\circ} \mathrm{C}, 36 \mathrm{~h}$ $58 \%, 88 \%$ ee

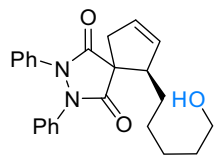

3oa, $30^{\circ} \mathrm{C}, 36 \mathrm{~h}$ $66 \%, 93 \%$ ee

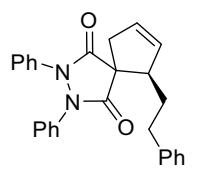

3 ta, $30{ }^{\circ} \mathrm{C}, 36 \mathrm{~h}$ $60 \%, 88 \%$ ee

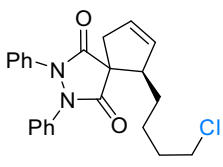

3 pa, $40{ }^{\circ} \mathrm{C}, 36 \mathrm{~h}$ $59 \%, 95 \%$ ee

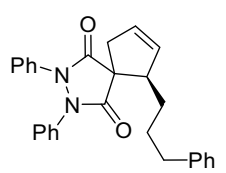

3ua, $30{ }^{\circ} \mathrm{C}, 36 \mathrm{~h}$ $62 \%, 94 \%$ ee bioactive tocopherol-derived 1,3-enyne

Fig. 2 Pd/WingPhos catalyzed cycloaddition of 1,3-enynes having a double bond with pyrazolidine-3,5-dione. The reactions were carried out on a 0.1mmol scale. Isolated yields are reported.

\section{Results}

Optimization of reaction conditions. We began the research by examining the cycloaddition reaction of 1,3-enynes having a terminal double bond with pyrazolidine-3,5-diones, a class of important heterocyclic scaffolds, which are widely present in biologically active molecules and pharmaceutical compounds ${ }^{47-50}$, for the asymmetric synthesis of spiro-pyrazolidine-3,5-diones. Spiro-pyrazolidine-3,5-diones have been shown to possess valuable biological properties, as exemplified by their use as AT1 angiotensin II receptor antagonists (Fig. 1b). However, there are no reports of catalytic asymmetric synthesis of spiro-pyrazolidine3,5-diones, thus limiting their potential applications in discovering chiral bioactive molecules. The model reaction of 1,3-enyne 1a with pyrazolidine-3,5-dione 2a was initially investigated at $\mathrm{CH}_{3} \mathrm{CN}$ in the presence of various chiral palladium catalysts. Most axially chiral ligands tested were either unreactive or gave double intermolecular hydroalkylation product rather than cyclization product. Selected results are shown in Table 1 (for the details, see Supplementary Tables 1-3 in the Supplementary Information). When planar-chiral Xylyl-PhanePhos (L6) was used as the ligand, spirocyclic product 3 aa was obtained in $44 \%$ yield but with only $21 \%$ ee, together with double intermolecular hydroalkylation product 4aa in $16 \%$ yield (Table 1, entry 6). Obviously, achieving the enantioselective cycloaddition of 1,3-enyne 1a with pyrazolidine-3,5-dione $\mathbf{2 a}$ with high enantiocontrol has posed a unique challenge, and it requires an efficient chiral catalytic system which has multifunctional roles (reactive, product-selective/pathway-selective, and enantioselective). Such a chiral catalyst should not only activate 1,3-enye $\mathbf{1 a}$ to generate the terminal Pdbutadienyl complex by $\mathrm{PdH}$-mediated migratory insertion and catalyze the selective formation of cycloaddition product rather than double intermolecular hydroalkylation product, but also 


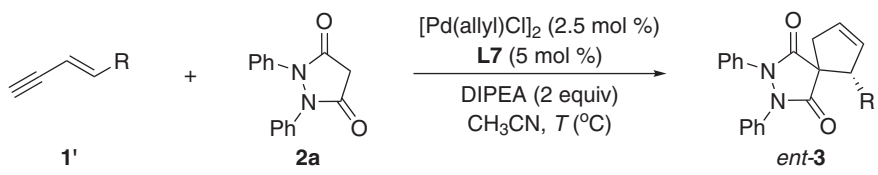

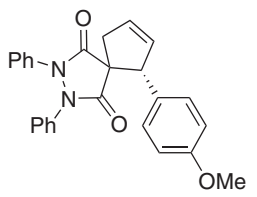

ent-3aa

$30^{\circ} \mathrm{C}, 12 \mathrm{~h}$

$62 \%, 86 \%$ ee

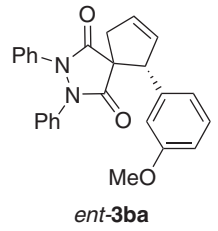

$30^{\circ} \mathrm{C}, 12 \mathrm{~h}$

$67 \%, 91 \%$ ee
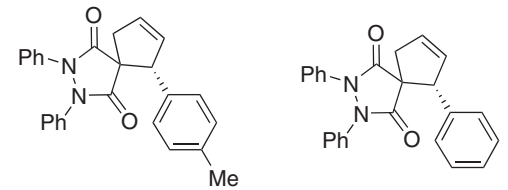

ent-3da
$30^{\circ} \mathrm{C}, 12$

$61 \%, 93 \%$ ee

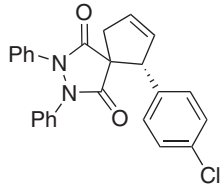

ent-3fa

$30{ }^{\circ} \mathrm{C}, 12 \mathrm{~h}$

$64 \%, 94 \%$ ee

$30^{\circ} \mathrm{C}, 12 \mathrm{~h}$

$63 \%, 94 \%$ ee

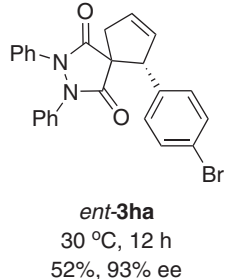

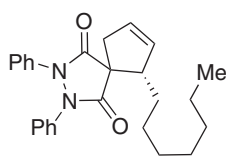

ent-3ma

$40{ }^{\circ} \mathrm{C}, 36 \mathrm{~h}$

$62 \%, 85 \%$ ee

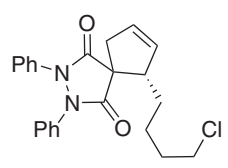

ent-3pa

$40^{\circ} \mathrm{C}, 36 \mathrm{~h}$

$60 \%, 86 \%$ ee

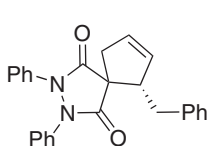

ent-3sa ${ }^{a}$

$40^{\circ} \mathrm{C}, 22 \mathrm{~h}$

$58 \%$, $88 \%$ ee

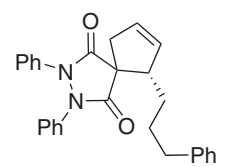

ent-3ua

$40^{\circ} \mathrm{C}, 36 \mathrm{~h}$

$66 \%, 89 \%$ ee

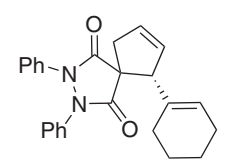

ent-3wa ${ }^{a}$

$40^{\circ} \mathrm{C}, 22 \mathrm{~h}$ $62 \%, 93 \%$ ee

Fig. 3 Pd/WingPhos catalyzed cycloaddition of 1,3-enynes having a triple bond with enantioselectivity switch. The reactions were carried out on a 0.1mmol scale. Isolated yields are reported. $\mathbf{L} 8$ was used as ligand. DIPEA N,N-diisopropylethylamine.

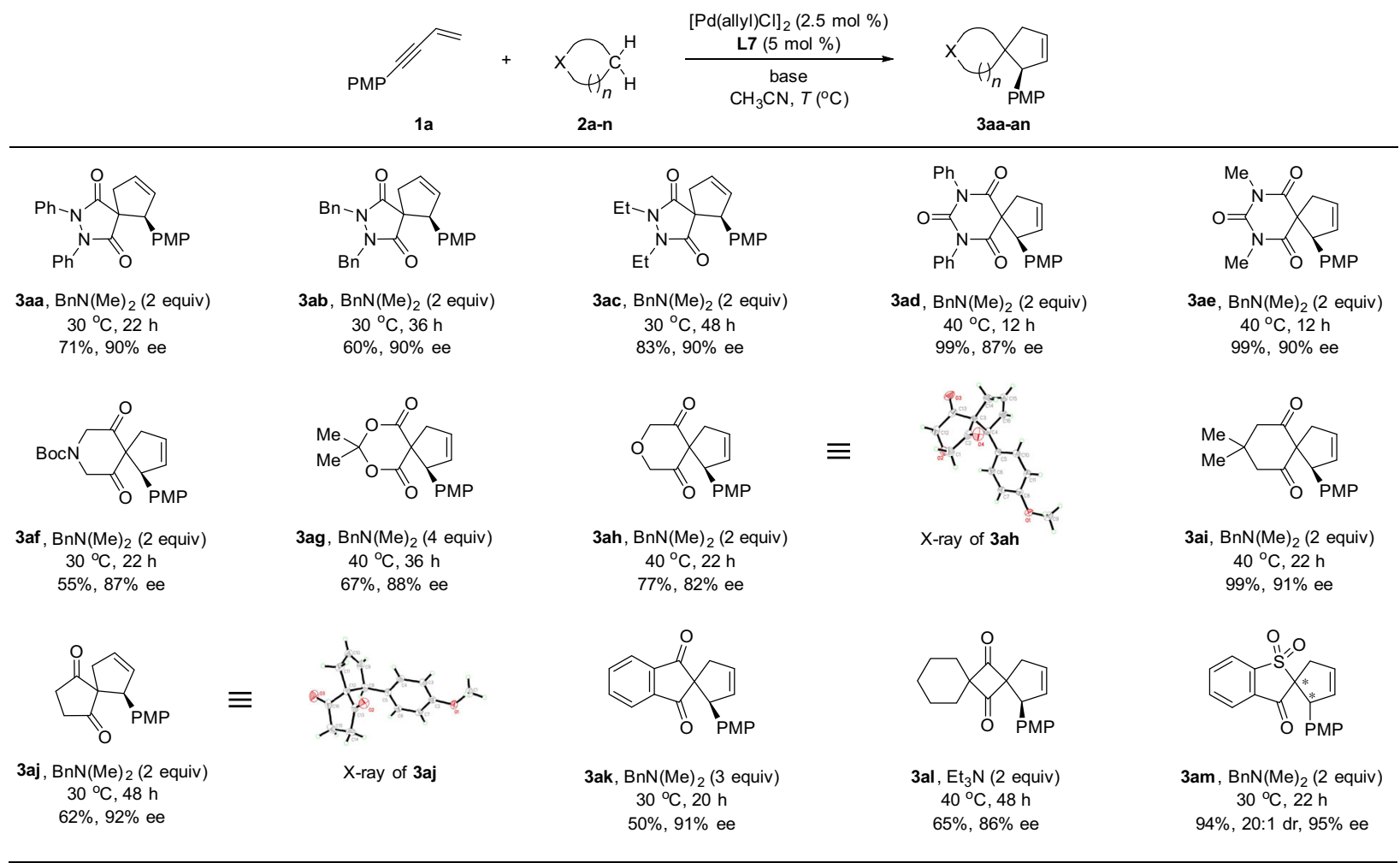

Fig. 4 Pd/WingPhos catalyzed enyne cycloaddition with various cyclic pronucleophiles. The reactions were carried out on a 0.1-mmol scale. Isolated yields are reported.

provide high levels of enantiocontrol. To our knowledge, the catalytic asymmetric cycloaddition which involves the terminal metal-butadienyl intermediates has not been previously reported.

Tang and co-workers recently introduced P-chiral BIBOP-type ligands for various asymmetric catalytic reactions ${ }^{51-54}$. To our knowledge, this class of chiral ligands have not been successfully applied in the catalytic asymmetric hydroalkylation process of unactivated unsaturated hydrocarbons with enols/enolates. We tested this type of chiral ligands in the reaction of 1,3-enyne 1a and pyrazolidine-3,5-dione $\mathbf{2 a}$, and found that WingPhos afforded promising results, with the formation of the desired spirocyclic product $\mathbf{3}$ aa as the major product with high enantiocontrol (Table 1, entry 7). To further suppress the second intermolecular hydroalkylation to form the undesired non- 
a

PMP

1a, 1.2 equiv

2a, $4 \mathrm{mmol}$<smiles>N#[Y16]C1C=CCC12C(=O)N(c1ccccc1)N(c1ccccc1)C2=O</smiles>

3aa, $1.1 \mathrm{~g}, 70 \%, 93 \%$ ee

b

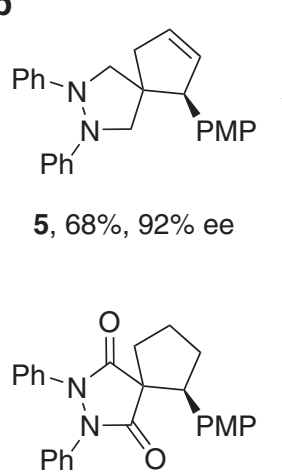

DIBAL-H
toluene
$-78^{\circ} \mathrm{C}, 5 \mathrm{~h}$

$5 \mathrm{~h}$

$\frac{\mathrm{Pd} / \mathrm{C}, \mathrm{H}_{2}}{\mathrm{EtOAC}}$<smiles>[R16]C1CC=CC12C(=O)N(c1ccccc1)C(=O)N2c1ccccc1</smiles>

6, $93 \%, 93 \%$ ee
$\frac{\mathrm{NBS}}{\mathrm{CH}_{3} \mathrm{OH}}$

3aa, $93 \%$ ee
NBS

$\mathrm{THF} / \mathrm{H}_{2} \mathrm{O}$

$\mathrm{RT}, 24 \mathrm{~h}$

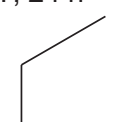<smiles>O=C1N(c2ccccc2)N(c2ccccc2)C(=O)C12C[C@H](O)[C@H](Br)[C@H]2P</smiles>

8, 71\%, > 20:1 dr $93 \%$ ee

$\underset{\mathrm{NaOH}}{\longrightarrow}$ $\mathrm{Et}_{2} \mathrm{O}$ RT, $5 \mathrm{~h}$<smiles>O=C1N(c2ccccc2)N(c2ccccc2)C(=O)C12C[C@@H](O)C=C2P</smiles>

9, $86 \%$<smiles>O=C1N(c2ccccc2)N(c2ccccc2)C(=O)C12CC1OC1[C@@H]2P</smiles>

$10,74 \%,>20: 1 \mathrm{dr}$ $94 \%$ ee

C<smiles>CCC1C=CCC12C(=O)N(c1ccccc1)N(c1ccccc1)C2=O</smiles>

3ma, 94\% ee

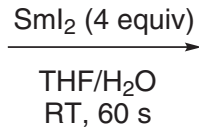

RT, $60 \mathrm{~s}$

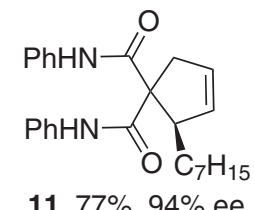

11, $77 \%, 94 \%$ ee

Fig. 5 Synthetic applications. a Gram-scale experiment. b Synthetic transformations of product 3aa (hydrogenation, alkoxybromination, hydroxybromination, and epoxidation of $\mathrm{C}=\mathrm{C}$ double bond, reduction of amide group). c Synthetic transformation of product $\mathbf{3 m a}$ (reductive cleavage of the N-N bond). DIBAL-H diisobutylaluminum hydride, NBS N-Bromosuccinimide, $m$-CPBA $m$-Chloroperbenzoic acid, THF tetrahydrofuran, DCM dichloromethane.

annulative double hydroalkylation product $4 \mathbf{a a}$, the temperature was decreased. The non-annulative double hydroalkylation product 4aa was fully suppressed, unfortunately, the reaction conversion decreased (Table 1, entry 8 ). We found that bases had a crucial effect on the reaction conversion (Table 2). $\mathrm{BnN}(\mathrm{Me})_{2}$, which has rarely been used as the base in organic synthesis, provided the desired spirocyclic product 3 aa in $71 \%$ yield with $90 \%$ ee (Table 2 , entry 5 versus entries $1-4$ ).

Substrate scope. With optimized chiral catalyst system and reaction conditions, a range of 1,3-enynes 1 have been examined for the cycloaddition reaction with 2 a (Fig. 2).

(Hetero)aryl-substituted 1,3-enynes afforded spirocyclized products $\mathbf{3} \mathbf{a} \mathbf{a}-\mathbf{3 j a}$ in good yields with high enantioselectivities. A 1,3-disubstituted enyne $\mathbf{1 k}$ also led to the spirocyclized product $3 \mathbf{k a}$ in $65 \%$ yield with $93 \%$ ee. Notably, alkyl-substituted 1,3enynes were also suitable substrates for this transformation (3la-3ua). Several functional groups were well tolerated, including esters, nitriles, halides, and free alcohols. Furthermore, alkenyl-substituted 1,3-enynes also underwent the cycloaddition to afford the corresponding spirocyclized products (3va-3wa). It is worth noting that such substrates have rarely been used in the reactions by transition-metal hydride catalysis, as could potentially generate multiple regioisomers of the butadienyl palladium intermediates and could lead to side products. 1,4-Disubstituted enynes did not work due to steric bulkiness. The absolute configuration of 3ea was determined by X-ray crystal analysis (for the details, see Supplementary Table 4 in the Supplementary Information).

Notably, Pd/WingPhos catalyst also permitted the asymmetric cycloaddition reaction of 1,3-enynes having a terminal triple bond (Fig. 3). More interestingly, a switch of enantioselectivity was observed as compared with 1,3-enyne substrates having a terminal double bond.

A variety of diverse pronucleophiles, including biologically active structural cores, can be flexibly incorporated into spirocyclic scaffolds by Pd/WingPhos catalyzed enyne cycloaddition. As illustrated in Fig. 4, pyrazolidine-3,5-diones $2 \mathrm{a}-2 \mathrm{c}$ reacted smoothly with 1,3-enyne 1a, delivering spiro-pyrazolidine-3,5- 
a<smiles>CCCCCCCCC=CCCC1C(=O)N(c2ccccc2)N(c2ccccc2)C1=O</smiles>

rac-13

b

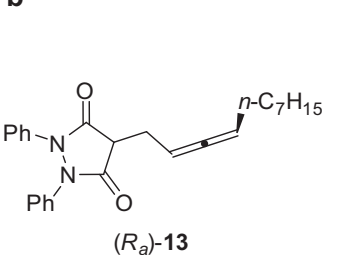<smiles>CCCCCCCCCC=CCCC1C(=O)N(c2ccccc2)N(c2ccccc2)C1=O</smiles>

$\left(S_{a}\right)-13$
$\left[\mathrm{Pd}(\text { allyl)Cl}]_{2}(2.5 \mathrm{~mol} \%)\right.$ L7 (5 $\mathrm{mol} \%)$

$\mathrm{BnN}(\mathrm{Me})_{2}$ (2 equiv)

$\mathrm{CH}_{3} \mathrm{CN}, 30{ }^{\circ} \mathrm{C}, 16 \mathrm{~h}$

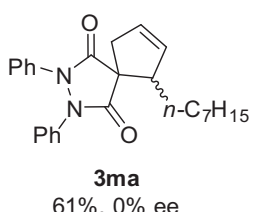

$61 \%, 0 \%$ ee

$85 \%, 94 \%$ ee

$\underset{\substack{\mathrm{BnN}(\mathrm{Me})_{2}(2 \text { equiv }) \\ \mathrm{CH}_{3} \mathrm{CN}, 30^{\circ} \mathrm{C}, 16 \mathrm{~h}}}{[\mathrm{Pd}(\text { allyl }) \mathrm{Cl}]_{2}(2.5 \mathrm{~mol} \%)}$

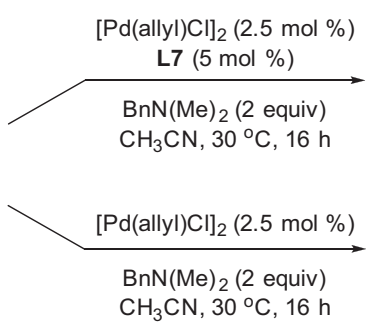

$[\mathrm{Pd}(\text { allyl }) \mathrm{Cl}]_{2}(2.5 \mathrm{~mol} \%)$ $\underset{\mathrm{BnN}(\mathrm{Me})_{2}(2 \text { equiv })}{\stackrel{\text { L7 }(5 \mathrm{~mol} \%)}{\mathrm{CH}_{3} \mathrm{CN}, 30^{\circ} \mathrm{C}, 16 \mathrm{~h}}}$

d

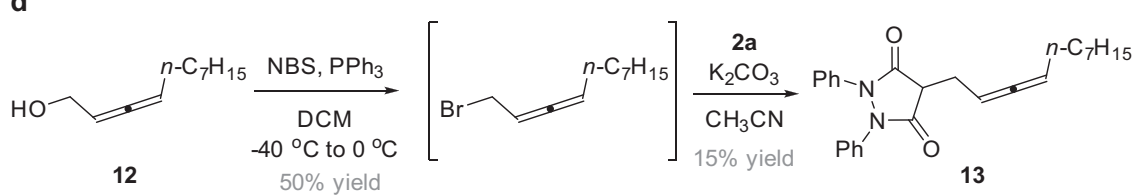

12 $50 \%$ yield

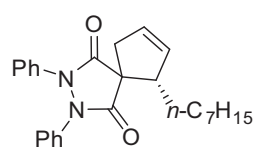

(S)-3ma

$65 \%, 92 \%$

$$
\text { rac-12 }
$$

Fig. 6 Mechanistic experiments. a The cyclization of rac-13 led to the spirocyclic product $\mathbf{3 m a}$ with $0 \%$ ee. b The cyclization of $\left(R_{a}\right)$-13 afforded $(R)$-3ma in $62 \%$ yield with $94 \%$ ee. c The cyclization of $\left(S_{a}\right)-\mathbf{1 3}$ afforded $(S)-\mathbf{3 m a}$ in $65 \%$ yield with $92 \%$ ee. $\mathbf{d}$ The preparation of the allene intermediate $\mathbf{1 3}$ from allenyl alcohol 12. NBS N-Bromosuccinimide.

diones 3aa-3ac. Barbiturates 2d-2e also took part in the enyne cycloaddition to produce spiro-barbiturates 3ad-3ae in good yields with good enantioselectivityies. Piperidine-3,5-dione $\mathbf{2 f}$ also participated, delivering spiro-piperidine-3,5-dione 3 af in $55 \%$ yield with $87 \%$ ee. O-heterocycles, such as meldrum's acid $\mathbf{2 g}$ and $2 \mathrm{H}$-pyran-3,5(4H,6H)-dione $\mathbf{2 h}$, were also suitable reaction partners for the spiroannulation. Six-, five-, and four-membered carbocycles $\mathbf{2} \mathbf{i}-\mathbf{2 l}$ all took part in the enyne cycloaddition reactions to deliver spirocyclized products 3ai-3al. Prochiral pronucleophiles also underwent smoothly the enyne cycloaddition reactions. For example, benzo[b]thiophen-3(2H)-one 1,1dioxide $\mathbf{2 m}$ afforded the spirocyclic product $\mathbf{3 a m}$ in good yield (94\%) with both high diastereoselectivity (20:1 dr) and enantioselectivity ( $95 \%$ ee). Interestingly, acyclic 1,3-dicarbonyl compounds did not work under the present chiral catalyst system. The absolute configuration of $\mathbf{3 a h}$ and 3aj was determined by X-ray crystal analysis, respectively (for the details, see Supplementary Tables 5-6 in Supplementary Information).

Synthetic applications. To demonstrate the practicability of our method, a gram-scale synthesis of the spirocyclic compound 3aa was conducted without loss of the yield and enantioselectivity (Fig. 5a). The olefin group provided a versatile handle for rapid diversification to afford highly functionalized spirocyclic compounds 6-10 with up to three contiguous stereocenters (Fig. 5b). The amide group could be reduced by DIBAL-H to deliver valuable spiro-pyrazolidine 5 . The $\mathrm{N}-\mathrm{N}$ bond of $\mathbf{3 m a}$ could be cleaved with $\mathrm{SmI}_{2}$ to afford functionalized cyclopentene 11 without loss of the enantioselectivity ${ }^{55}$.

Mechanistic studies. In order to gain insight into the reaction mechanism and understand the origin of the high enantioselectivity we observed in the Pd/WingPhos-catalyzed enantioselective cycloaddition reaction of 1,3-enynes 1 , a series of experiments have been conducted (Fig. 6). We prepared the allene intermediates rac-13, $\left(R_{a}\right)-13$, and $\left(S_{a}\right)$-13 from pre-functionalized allenylic partners, rac-12, $\left(R_{a}\right)-\mathbf{1 2}\left(93 \%\right.$ ee), and $\left(S_{a}\right)-\mathbf{1 2}$ (94\% ee), respectively (We could not isolate the corresponding allene intermediate during the $\mathrm{Pd} /$ WingPhos-catalyzed cycloaddition reaction of $\mathbf{1 a}$ and $\mathbf{2 a}$ ), and subjected them to the conditions of the enantioselective catalytic reaction. The cyclization of rac-13 led to the spirocyclic product $3 \mathrm{ma}$ with $0 \%$ ee (Fig. $6 \mathrm{a}$ ), whereas the cyclization of $\left(R_{a}\right)-13$ afforded $(R)-3 \mathrm{ma}$ in $62 \%$ yield with 94\% ee (Fig. 6b) and the cyclization of $\left(S_{a}\right)-13$ afforded $(S)-3 \mathbf{m a}$ in $65 \%$ yield and $92 \%$ ee (Fig. $6 \mathrm{c}$ ). Taken together, these results suggest that axial chirality of the allene intermediates in situ generated via the $\mathrm{Pd} / \mathrm{WingPhos}$-catalyzed enantioselective intermolecular hydroalkylation of 1,3-enynes 1 with cyclic enols/ enolates likely serves as a chiral relay during the cyclization process involving a very high efficiency of axial-to central chirality transfer. In addition, the axially chiral allenes in situ generated must be stable to racemization under the reaction 

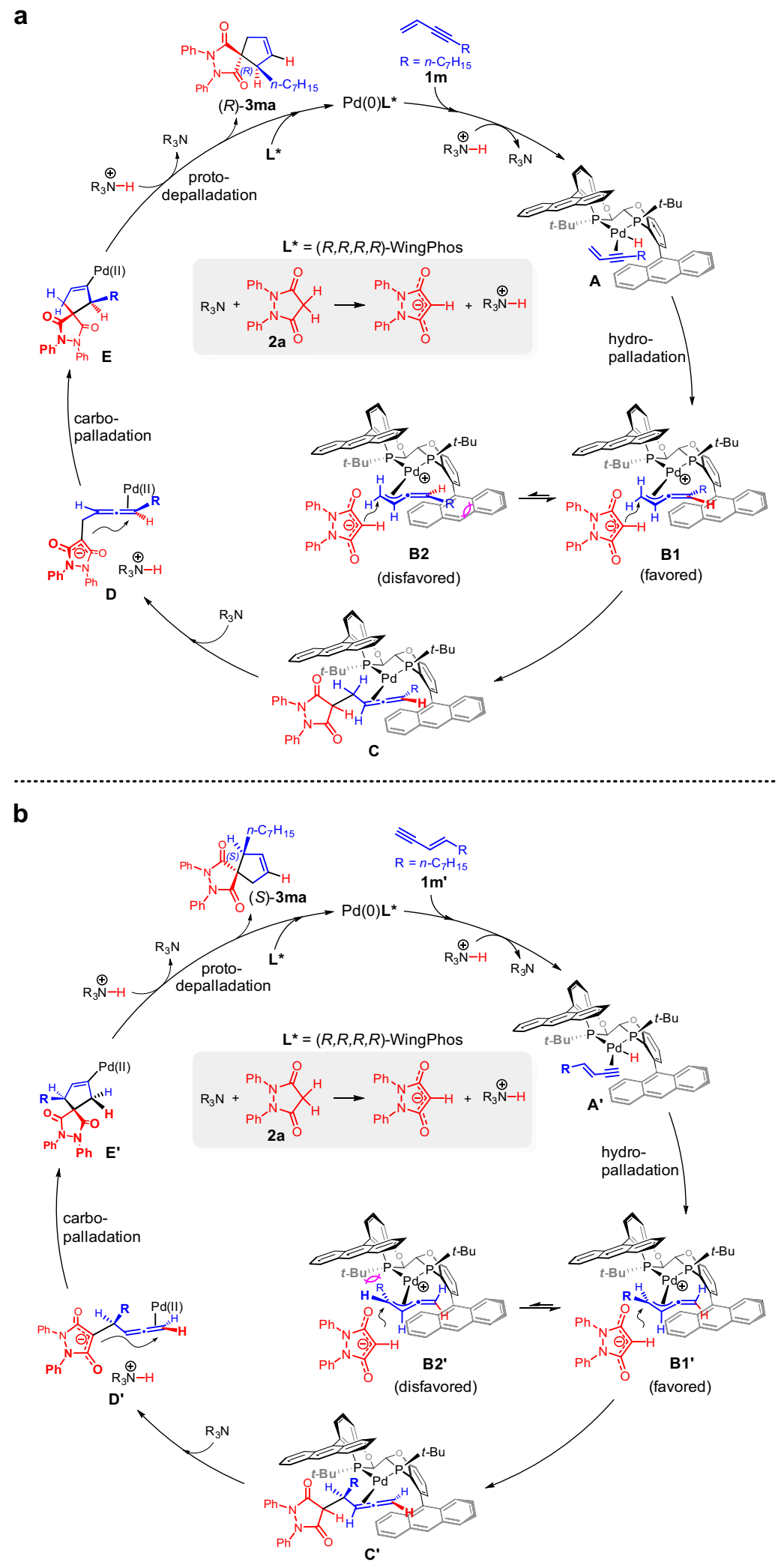

Fig. 7 Proposed catalytic cycle. a The cycloaddition reaction with 1,3-enyne $\mathbf{1 m}$ having a terminal double bond. $\mathbf{b}$ The cycloaddition reaction with 1,3-enyne $\mathbf{1} \mathbf{m}^{\prime}$ having a terminal triple bond.

conditions; otherwise no chirality transfer could be obtained. We also found that the allene intermediates $\left(R_{a}\right)-13$ in the absence of ligand provided $(R)$-3ma in much higher yield $(85 \%$ yield) with the same enantioselectivity ( $94 \%$ ee) (Fig. 6b).
On the basis of the above mechanistic studies and previous reports ${ }^{36}$, a plausible catalytic cycle for the cycloaddition reaction of 1,3-enynes is proposed in Fig. 7. The cycloaddition reaction of 1,3-enyne $1 \mathrm{~m}$ having a terminal double bond involves the 
a

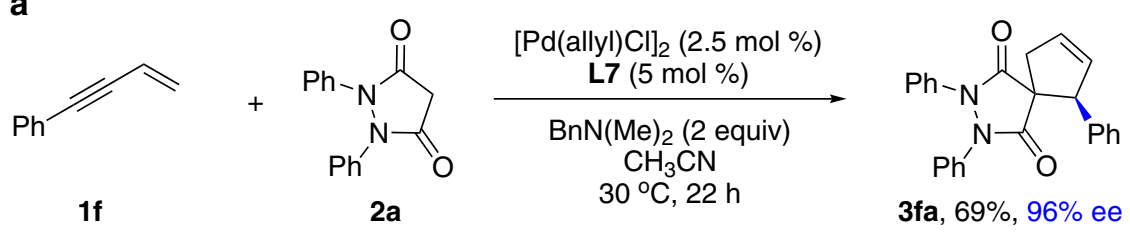

b<smiles>CC(=O)OC/C=C/C=C/c1ccccc1</smiles>

$[\mathrm{Pd}(\text { allyl }) \mathrm{Cl}]_{2}(2.5 \mathrm{~mol} \%)$ L7 (5 mol \%)

$\mathrm{BnN}(\mathrm{Me})_{2}$ (2 equiv)

$\mathrm{CH}_{3} \mathrm{CN}$

$30^{\circ} \mathrm{C}, 22 \mathrm{~h}$<smiles>O=C1N(c2ccccc2)N(c2ccccc2)C(=O)C12CC=C[C@H]2c1ccccc1</smiles>

3fa, $66 \%, 76 \%$ ee

c<smiles>C#C/C=C/Pc1ccccc1</smiles>

$1 f^{\prime}$

d<smiles>C=C=CC(OC(C)=O)c1ccccc1</smiles><smiles>O=C1CC(=O)N(c2ccccc2)N1c1ccccc1</smiles>

2a

$$
\begin{gathered}
\begin{array}{c}
{[\mathrm{Pd}(\text { allyl }) \mathrm{Cl}]_{2}(2.5 \mathrm{~mol} \%)} \\
\mathbf{L 7}(5 \mathrm{~mol} \%)
\end{array} \\
\begin{array}{c}
\text { DIPEA (2 equiv), } \mathrm{CH}_{3} \mathrm{CN} \\
30^{\circ} \mathrm{C}, 12 \mathrm{~h}
\end{array}
\end{gathered}
$$<smiles>O=C1CC(=O)N(c2ccccc2)N1c1ccccc1</smiles><smiles>O=C1N(c2ccccc2)N(c2ccccc2)C(=O)C12CC=CC2c1ccccc1</smiles>

ent-3fa, 50\%, 93\% ee

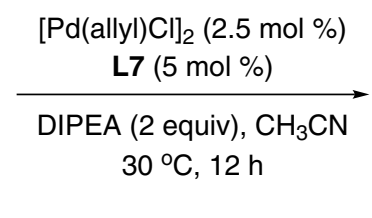

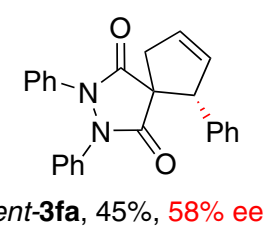

Fig. 8 Comparison experiments. a The cycloaddition of enyne $\mathbf{1 f}$ via the terminal Pd-butadienyl intermediate generated by PdH catalysis. b The cycloaddition of 2,3-allenyl acetate 1f" via the terminal Pd-butadienyl intermediate generated by oxidative addition. c The cycloaddition of enyne $\mathbf{1 f}$ ' via the internal Pd-butadienyl intermediate generated by PdH catalysis. d The cycloaddition of 2,3-allenyl acetate $\mathbf{1 f}^{\prime \prime \prime}$ via the internal Pd-butadienyl intermediate generated by oxidative addition. DIPEA $N, N$-diisopropylethylamine.

terminal Pd-butadienyl intermediate (Fig. 7a). First, the PdH species likely coordinates to 1,3 -enyne $\mathbf{1} \mathbf{m}$ to form the complex $\mathbf{A}$ which undergoes migratory alkyne insertion ${ }^{36}$ to produce the terminal butadienyl-Pd B1 or B2. Due to severe steric repulsion in B2, B1 is favored to undergo the intermolecular nucleophilic attack to afford chiral 1,3-disubstituted allene intermediate $\mathbf{C}$ with axial chirality. Subsequently, the intramolecular carbopalladation $^{56}$ of the chiral allene intermediate $\mathbf{D}$ forms $\mathbf{E}$ through a very high efficiency of axial-to central chirality transfer. The protodepalladation of $\mathbf{E}$ produces the spirocyclic product (R)-3ma. For the cycloaddition reaction of 1,3-enyne $\mathbf{1} \mathbf{m}^{\prime}$ having a terminal triple bond which involves the internal Pd-butadienyl intermediate (Fig. 7b), the intermolecular hydroalkylation of 1,3enyne $\mathbf{1} \mathbf{m}^{\prime}$ serves as the enantiodetermining step in which monosubstituted allene intermediate $\mathbf{C}^{\prime}$ with central chirality is formed.

Finally, we were interested in seeing whether the Pd-butadienyl intermediates generated by $\mathrm{PdH}$ insertion of 1,3-enynes differ with the corresponding intermediates generated by oxidative addition of allenol derivatives in reactivity or selectivity. We made the following comparison experiments (Fig. 8). Interestingly, the achiral enyne $\mathbf{l f}$ as the precursor provided the cycloaddition product $3 \mathrm{fa}$ in $69 \%$ yield with $96 \%$ ee (Fig. 8a) whereas the racemic 2,3-allenyl acetate $\mathbf{1 f}^{\prime \prime}$ as the precursor afforded the product $3 \mathrm{fa}$ in $66 \%$ yield with only $76 \%$ ee (Fig. 8b) under the identical reaction conditions. On the other hand, the achiral enyne $\mathbf{1 f}^{\prime}$ as the precursor provided the cycloaddition product ent-3fa in 50\% yield with $93 \%$ ee (Fig. 8c) whereas the racemic 2,3-allenyl acetate $\mathbf{1 f}^{\prime \prime \prime}$ as the precursor afforded the product ent-3fa in $45 \%$ yield with only $58 \%$ ee (Fig. 8d) under the identical reaction conditions. These results show the advantage and unique of the use of nonpolarized 1,3-enynes in the $\mathrm{PdH}$-catalyzed asymmetric cycloaddition reactions in terms of not only atom economy but also enantioselectivity.

\section{Discussion}

We have developed a PdH-based cycloaddition strategy for the enantioselective synthesis of a series of spirocyclic compounds directly from two classes of commonly available starting materials, 1,3-enynes and activated cyclic carbon-hydrogen $(\mathrm{C}-\mathrm{H})$ bonds. In the present atom economic cycloaddition, nonpolarized 1,3-enynes are utilized as dielectrophilic four-carbon units. By employing P-chiral WingPhos as the chiral ligand, the challenging product selectivity issue of cycloaddition products versus double intermolecular hydroalkylation products has been addressed. Notably, a chiral $\mathrm{Pd} /$ WingPhos catalyst affects the enantioswitchable enyne cycloaddition reactions with high levels of stereocontrol, thus providing a protocol for the enantioselectivity switch by exchanging the position of double bond and triple bond of 1,3-enyne substrates while maintaining the same absolute configuration of the chiral catalyst ${ }^{57-59}$. A variety of diverse cyclic nucleophiles including pharmaceutically important heterocycles and carbocycles can be flexibly and directly incorporated with spiro scaffolds. A broad range of functional groups of 1,3-enyne substrates, including alcohols, esters, nitriles, halides, and olefins, are tolerated. We believe this methodology may find considerable use and enable the discovery of chiral spirocyclic molecules with interesting biological activities.

\section{Methods}

Representative procedure for the cycloaddition. $[\mathrm{Pd}(\text { allyl }) \mathrm{Cl}]_{2}(0.91 \mathrm{mg}$ $2.5 \mathrm{~mol} \%$ ), and $\mathbf{L} 7(3.7 \mathrm{mg}, 5 \mathrm{~mol} \%)$ were dissolved in $\mathrm{CH}_{3} \mathrm{CN}(0.5 \mathrm{~mL})$ and stirred for $15 \mathrm{~min}$ at $30^{\circ} \mathrm{C}$ under Ar atmosphere. Subsequently, 1,3-enyne 1a 
(0.12 mmol, 1.2 equiv), pyrazolidine-3,5-dione $\mathbf{2 a}(0.1 \mathrm{mmol}, 1$ equiv), and $\mathrm{BnN}(\mathrm{Me})_{2}(0.2 \mathrm{mmol}, 2$ equiv) were added. The reaction mixture was stirred until the reaction completed. The solution was concentrated in vacuum and the crude product was purified by column chromatography on silica gel ( $n$-hexane/ $\mathrm{EtOAc}=95: 5)$ to afford the spiro-pyrazolidine-3,5-dione 3aa.

\section{Data availability}

The authors declare that the data supporting the findings of this study are available within the article and the Supplementary Information as well as from the authors upon reasonable request. The X-ray crystallographic coordinates for structures (S)-3ah, (S)-3aj, and (S)-3ea reported in this study have been deposited at the Cambridge Crystallographic Data Centre (CCDC), under CCDC 2086798, CCDC 2086799, and CCDC 2086800, respectively. These data can be obtained free of charge from The Cambridge Crystallographic Data Centre via www.ccdc.cam.ac.uk/data_request/cif.

Received: 22 June 2021; Accepted: 10 September 2021;

Published online: 27 September 2021

\section{References}

1. Le Bourdonnec, B. et al. Synthesis and pharmacological evaluation of new pyrazolidine-3,5-diones as $\mathrm{AT}_{1}$ angiotensin II receptor antagonists. J. Med. Chem. 43, 2685-2697 (2000).

2. Schlemminger, I. et al. Preparation of 1-(piperidin-4-yl)-4,5-dihydropyrazol-5-one derivatives as phosphodiesterase 4 (PD4) inhibitors. WO2010055083-A1 (2010).

3. Warnick-Pickle, D. J., Byrne, K. M., Pandey, R. C. \& White, R. J. Fredericamycin A, a new antitumor antibiotic. J. Antibiot. 34, 1402-1407 (1981).

4. Müller, G. et al. Charting biologically relevant spirocyclic compound space. Chem. Eur. J. 23, 703-710 (2017)

5. Renard, A., Lhomme, J. \& Kotera, M. Synthesis and properties of spiro nucleosides containing the barbituric acid moiety. J. Org. Chem. 67, 1302-1307 (2002).

6. Sandargo, B., Michehl, M., Stadler, M. \& Surup, F. Antifungal sesquiterpenoids, rhodocoranes, from submerged cultures of the wrinkled peach mushroom, rhodotus palmatus. J. Nat. Prod. 83, 720-724 (2020).

7. Heilmann, J., Winkelmann, K. \& Sticher, O. Studies on the antioxidative activity of phloroglucinol derivatives isolated from hypericum species. Planta Med. 69, 202-206 (2003)

8. Zheng, Y.-J. \& Tice, C. M. The utilization of spirocyclic scaffolds in novel drug discovery. Expert Opin. Drug Discov. 11, 831-834 (2016).

9. Zheng, Y., Tice, C. M. \& Singh, S. B. The use of spirocyclic scaffolds in drug discovery. Bioorg. Med. Chem. Lett. 24, 3673-3682 (2014).

10. Xu, P. et al. Catalytic enantioselective construction of spiro quaternary carbon stereocenters. ACS Catal. 9, 1820-1882 (2019).

11. Ding, A., Meazza, M., Guo, H., Yang, J. W. \& Rios, R. New development in the enantioselective synthesis of spiro compounds. Chem. Soc. Rev. 47, 5946-5996 (2018).

12. Kotha, S., Panguluri, N. R. \& Ali, R. Design and synthesis of spirocycles. Eur. J. Org. Chem. 2017, 5316-5342 (2017).

13. Carreira, E. M. \& Fessard, T. C. Four-membered ring-containing spirocycles: synthetic strategies and opportunities. Chem. Rev. 114, 8257-8322 (2014).

14. Franz, A. K., Hanhan, N. V. \& Ball-Jones, N. R. Asymmetric catalysis for the synthesis of spirocyclic compounds. ACS Catal. 3, 540-553 (2013).

15. Rios, R. Enantioselective methodologies for the synthesis of spiro compounds. Chem. Soc. Rev. 41, 1060-1074 (2012).

16. Kotha, S., Deb, A. C., Lahiri, K. \& Manivannan, E. Selected synthetic strategies to spirocyclics. Synthesis 2009, 165-193 (2009).

17. Pradhan, R., Patra, M., Behera, A. K., Mishra, B. K. \& Behera, R. K. A synthon approach to spiro compounds. Tetrahedron 62, 779-828 (2006).

18. Sannigrahi, M. Stereocontrolled synthesis of spirocyclics. Tetrahedron $\mathbf{5 5}$, 9007-9071 (1999)

19. Trost, B. M. The atom economy-a search for synthetic efficiency. Science 254, 1471-1477 (1991).

20. Shao, W., Besnard, C., Guénée, L. \& Mazet, C. Ni-catalyzed regiodivergent and stereoselective hydroalkylation of acyclic branched dienes with unstabilized $\mathrm{C}\left(\mathrm{sp}^{3}\right)$ nucleophiles. J. Am. Chem. Soc. 142, 16486-16492 (2020).

21. Zhang, Q. et al. Stereodivergent coupling of 1,3-dienes with aldimine esters enabled by synergistic $\mathrm{Pd}$ and $\mathrm{Cu}$ catalysis. J. Am. Chem. Soc. 141, 14554-14559 (2019).

22. Adamson, N. J., Wilbur, K. C. E. \& Malcolmson, S. J. Enantioselective intermolecular Pd-catalyzed hydroalkylation of acyclic 1,3-dienes with activated pronucleophiles. J. Am. Chem. Soc. 140, 2761-2764 (2018).

23. Park, S., Adamson, N. J. \& Malcolmson, S. J. Brønsted acid and Pd-PHOX dual-catalysed enantioselective addition of activated C-pronucleophiles to internal dienes. Chem. Sci. 10, 5176-5182 (2019).
24. Cheng, L., Li, M.-M., Xiao, L.-J., Xie, J.-H. \& Zhou, Q.-L. Nickel(0)-catalyzed hydroalkylation of 1,3-dienes with simple ketones. J. Am. Chem. Soc. 140 11627-11630 (2018)

25. Zhang, Z., Xiao, F., Wu, H.-M., Dong, X.-Q. \& Wang, C.-J. Pd-Catalyzed asymmetric hydroalkylation of 1,3-dienes: access to unnatural $\alpha$-amino acid derivatives containing vicinal quaternary and tertiary stereogenic centers. Org. Lett. 22, 569-574 (2020).

26. Yang, H. \& Xing, D. Palladium-catalyzed diastereo- and enantioselective allylic alkylation of oxazolones with 1,3-dienes under base-free conditions. Chem. Commun. 56, 3721-3724 (2020).

27. Xia, J. et al. Mechanistic study of $\mathrm{Ni}$ and $\mathrm{Cu}$ dual catalyst for asymmetric $\mathrm{C}-\mathrm{C}$ bond formation; asymmetric coupling of 1,3-dienes with C-nucleophiles to construct vicinal stereocenters. ACS Catal. 11, 6643-6655 (2021).

28. Zhou, H., Wang, Y., Zhang, L., Cai, M. \& Luo, S. Enantioselective terminal addition to allenes by dual chiral primary amine/palladium catalysis. J. Am. Chem. Soc. 139, 3631-3634 (2017).

29. Beck, T. M. \& Breit, B. Regio- and enantioselective rhodium-catalyzed addition of 1,3-diketones to allenes: construction of asymmetric tertiary and quaternary all carbon centers. Angew. Chem. Int. Ed. 56, 1903-1907 (2017).

30. Zhou, H. et al. From palladium to brønsted acid catalysis: highly enantioselective regiodivergent addition of alkoxyallenes to pyrazolones. Angew. Chem. Int. Ed. 56, 1077-1081 (2017).

31. Trost, B. M., Jäkel, C. \& Plietker, B. Palladium-catalyzed asymmetric addition of pronucleophiles to allenes. J. Am. Chem. Soc. 125, $4438-4439$ (2003).

32. Zhu, M., Zhang, Q. \& Zi, W. Diastereodivergent synthesis of $\beta$-amino alcohols by dual-metal-catalyzed coupling of alkoxyallenes with aldimine esters. Angew. Chem. Int. Ed. 60, 6545-6552 (2021).

33. Cruz, F. A. \& Dong, V. M. Stereodivergent coupling of aldehydes and alkynes via synergistic catalysis using Rh and Jacobsen's amine. J. Am. Chem. Soc. 139 1029-1032 (2017)

34. Lee, J. T. D. \& Zhao, Y. Direct enantioselective $\alpha$-allylation of unfunctionalized cyclic ketones with alkynes through Pd-amine cooperative catalysis. Chem. Eur. J. 24, 9520-9524 (2018).

35. Xie, L., Yang, H., Ma, M. \& Xing, D. Rhodium-catalyzed branched and enantioselective direct $\alpha$-allylic alkylation of simple ketones with alkynes. Org. Lett. 22, 2007-2011 (2020).

36. Adamson, N. J., Jeddi, H. \& Malcolmson, S. J. Preparation of chiral allenes through Pd-catalyzed intermolecular hydroamination of conjugated enynes: enantioselective synthesis enabled by catalyst design. J. Am. Chem. Soc. 141, 8574-8583 (2019)

37. Tsukamoto, H., Konno, T., Ito, K. \& Doi, T. Palladium(0)-lithium iodide cocatalyzed asymmetric hydroalkylation of conjugated enynes with pronucleophiles leading to 1,3-disubstituted allenes. Org. Lett. 21, 6811-6814 (2019).

38. Yang, S.-Q., Wang, Y.-F., Zhao, W.-C., Lin, G.-Q. \& He, Z.-T. Stereodivergent synthesis of tertiary fluoride-tethered allenes via copper and palladium dual catalysis. J. Am. Chem. Soc. 143, 7285-7291 (2021).

39. Fu, L., Greßies, S., Chen, P. \& Liu, G. Recent advances and perspectives in transition metal-catalyzed 1,4-functionalizations of unactivated 1,3-enynes for the synthesis of allenes. Chin. J. Chem. 38, 91-100 (2020).

40. Yang, L.-C. et al. Stereoselective access to [5.5.0] and [4.4.1] bicyclic compounds through Pd-catalysed divergent higher-order cycloadditions. Nat. Chem. 12, 860-868 (2020).

41. Chen, T. et al. Rhodium $(\mathrm{I}) / \mathrm{Zn}(\mathrm{OTf})_{2}$-catalyzed asymmetric ring opening/ cyclopropanation of oxabenzonorbornadienes with phosphorus ylides. Angew. Chem. Int. Ed. 58, 15819-15823 (2019).

42. Li, L., Luo, P.-F., Deng, Y.-H. \& Shao, Z.-H. Regioselectivity switch in palladium-catalyzed allenylic cycloadditions of allenic esters: $[4+1]$ or $[4+3]$ cycloaddition/cross-coupling. Angew. Chem. Int. Ed. 58, 4710-4713 (2019).

43. Kumari, P. et al. Palladium-catalyzed asymmetric [4+3]-cyclization reaction of fused 1-azadienes with amino-trimethylenemethanes: highly stereoselective construction of chiral fused azepines. Chin. J. Chem. 38, 151-157 (2020).

44. Lautens, M., Klute, W. \& Tam, W. Transition metal-mediated cycloaddition reactions. Chem. Rev. 96, 49-92 (1996).

45. D'yakonov, V. A., Trapeznikova, O. A., de Meijere, A. \& Dzhemilev, U. M. Metal complex catalysis in the synthesis of spirocarbocycles. Chem. Rev. 114, 5775-5814 (2014)

46. Chen, J.-R., Hu, X.-Q., Lu, L.-Q. \& Xiao, W.-J. Formal [4+1] annulation reactions in the synthesis of carbocyclic and heterocyclic systems. Chem. Rev. 115, 5301-5365 (2015).

47. Gilbert, A. M. et al. Pyrazolidine-3,5-diones and 5-hydroxy-1H-pyrazol$3(2 \mathrm{H})$-ones, inhibitors of UDP- $\mathrm{N}$-acetylenolpyruvyl glucosamine reductase. J. Med. Chem. 49, 6027-6036 (2006).

48. Kutterer, K. M. K. et al. 4-Alkyl and 4,4'-dialkyl 1,2-bis(4-chlorophenyl) pyrazolidine-3,5-dione derivatives as new inhibitors of bacterial cell wall biosynthesis. Bioorg. Med. Chem. Lett. 15, 2527-2531 (2005).

49. Krogdal, T. G. The use of 3,5-pyrazolidinedione derivatives to combat viral infections. WO200054771-A1 (2000). 
50. Cederbaum, F., Brunner, H. G. \& Boeger, M. Herbicidally, acaricidally, and insecticidially active pyrazolidine-3,5-dione derivatives and their preparation. WO9216510-A1 (1992).

51. Liu, G. et al. Design of phosphorus ligands with deep chiral pockets: practical pynthesis of chiral $\beta$-arylamines by asymmetric hydrogenation. Angew. Chem. Int. Ed. 52, 4235-4238 (2013).

52. Huang, L. et al. Highly Enantioselective rhodium-catalyzed addition of arylboroxines to simple aryl ketones: efficient synthesis of escitalopram. Angew. Chem. Int. Ed. 55, 4527-4531 (2016).

53. Zhu, J. et al. Enantioselective rhodium-catalyzed addition of arylboroxines to $\mathrm{N}$-unprotected ketimines: efficient synthesis of cipargamin. Angew. Chem. Int. Ed. 58, 16119-16123 (2019).

54. Xu, G., Senanayake, C. H. \& Tang, W. P-chiral phosphorus ligands based on a 2,3-dihydrobenzo[d][1,3] oxaphosphole motif for asymmetric catalysis. Acc. Chem. Res. 52, 1101-1112 (2019).

55. Guazzelli, G. et al. Selective reductions of cyclic 1,3-diesters using $\mathrm{SmI}_{2}$ and $\mathrm{H}_{2}$ O. J. Am. Chem. Soc. 131, 7214-7215 (2009).

56. Ma, S. \& Gao, W. Efficient synthesis of 4-(2'-alkenyl)-2,5-dihydrofurans and 5,6-dihydro-2H-pyrans via the Pd-catalyzed cyclizative coupling reaction of 2,3- or 3,4-allenols with allylic halides. J. Org. Chem. 67, 6104-6112 (2002).

57. Beletskaya, I. P., Nájera, C. \& Yus, M. Stereodivergent catalysis. Chem. Rev. 118, 5080-5200 (2018).

58. Bartók, M. Unexpected inversions in asymmetric reactions: reactions with chiral metal complexes, chiral organocatalysts, and heterogeneous chiral catalysts. Chem. Rev. 110, 1663-1705 (2010).

59. Tanaka, T. \& Hayashi, M. New approach for complete reversal of enantioselectivity using a single chiral source. Synthesis 2008, 3361-3376 (2008).

\section{Acknowledgements}

This work was supported by the National Natural Science Foundation of China (21861042, 21801221), the Program for Changjiang Scholars and Innovative Research Team in University (IRT17R94), the Open Research Program of State Key Laboratory for Conservation and Utilization of Bio-Resources in Yunnan (2019KF010), the Program for Innovative Research Team (in Science and Technology) in University of Yunnan Province, and Yunling Scholar of Yunnan Province. We thank Advanced Analysis and Measurement Center of Yunnan University for the sample testing service.

\section{Author contributions}

Z.S. conceived and directed the project. L.L., S.W., P.L., and R.W. performed the experiments. Z.W. and X.L. performed mechanistic study. Y.D., F.P., and Z.S. analyzed the results and wrote the manuscript.

\section{Competing interests}

The authors declare no competing interests.

\section{Additional information}

Supplementary information The online version contains supplementary material available at https://doi.org/10.1038/s41467-021-25981-x.

Correspondence and requests for materials should be addressed to Zhihui Shao.

Peer review information Nature Communications thanks Jianxiao $\mathrm{Li}$ and the other anonymous reviewer(s) for their contribution to the peer review of this work.

Reprints and permission information is available at http://www.nature.com/reprints

Publisher's note Springer Nature remains neutral with regard to jurisdictional claims in published maps and institutional affiliations.

(c) (i) Open Access This article is licensed under a Creative Commons Attribution 4.0 International License, which permits use, sharing, adaptation, distribution and reproduction in any medium or format, as long as you give appropriate credit to the original author(s) and the source, provide a link to the Creative Commons license, and indicate if changes were made. The images or other third party material in this article are included in the article's Creative Commons license, unless indicated otherwise in a credit line to the material. If material is not included in the article's Creative Commons license and your intended use is not permitted by statutory regulation or exceeds the permitted use, you will need to obtain permission directly from the copyright holder. To view a copy of this license, visit http://creativecommons.org/ licenses/by/4.0/.

(C) The Author(s) 2021 